九州大学学術情報リポジトリ

Kyushu University Institutional Repository

\title{
THE CERAMBYCIDAE (COLEOPTERA) OF NEPAL COLLECTED BY THE KYUSHU UNIVERSITY SCIENTIFIC EXPEDITION
}

Hayashi, Masao

Makihara, Hiroshi

https://doi.org/10.5109/2420

出版情報: ESAKIA. 17，pp.183-200，1981-11-30. Entomological Laboratory，Faculty of Agriculture, Kyushu University

バージョン：

権利関係 : 


\title{
THE CERAMBYCIDAE (COLEOPTERA) OF NEPAL COLLECTED BY THE KYUSHU UNIVERSITY SCIENTIFIC EXPEDITION ${ }^{12)}$
}

\author{
M ASAO H AYASHI \\ Osaka Jonan Women's College, \\ Higashi-sumiyoshi-ku, Osaka 546, Japan \\ and \\ H iroshi MAKIHARA ${ }^{3)}$ \\ Entomological Laboratory, Faculty of Agriculture, \\ Kyushu University, Fukuoka 812, Japan
}

\begin{abstract}
The subfamilies Prioninae, Lepturinae and Cerambycinae of the family Cerambycidae taken by the Kyushu University Scientific Expedition to the Nepal Himalaya in 1971 and 1972 are dealt. Out of 24 species, 5 species, Strangaliella emotoi, Idiostrangalia quadrisignata, Rosalia (Eurybatus) nakanishii, Glaphyra shimai and Rhaphuma nishidai are described as new and 6 species, Xylotrechus quadripes Chevrolat, X. incurvatus contorsus Gahan, Chlorophorus shoreae Gardner, Rhapkuma fulgurata Gahan, Aglaophis fasciata Thomson and Artimpaza obscura Gardner are recorded from Nepal for the first time.
\end{abstract}

The Cerambycidae of Nepal have been rather poorly known to science since Hope (1381), in comparison with the surrounding regions such as Sikkim, Assam and Burma or even Kashmir and Bhutan. Recently Villiers et Châjô̂ (1966) and Hayashi (1979, 1980) have contributed toward the knowledge of the Nepalese Cerambycidae based on the material brought back by Japanese expeditions.

This paper reports the results of our study on the material of the subfamilies Prioninae, Lepturinae and Cerambycinae of the family Cerambycidae taken by the Kyushu University Scientific Expedition to the Nepal Himalaya in

1) Contribution from the Entomological Laboratory, Faculty of Agriculture, Kyushu University, Fukuoka (Ser. 3, No. 99).

2) Results of the Kyushu University Scientific Expedition to the Nepal Himalaya. Coleoptera 1.

3) Present address: Division of Forest Protection, Forestry \& Forest Products Research Institute, Tsukuba Norin Kenkyu Danchi, Ibaraki 305, Japan. 
1971 and 1972. It includes 24 species, of which 5 species are described here as new to science, and 6 species are recorded from Nepal for the first time (indicated by an asterisk).

The material was collected by the members of the expedition; A. Nakanishi in 1971, and H. Shima, Y. Nishida, J. Emoto and H. Makihara in 1972.

Their collecting routes are from Bogara to Dobang, Central Nepal in 1971, and from Biratnagar to Thudam, East Nepal in 1972 (Map 1).

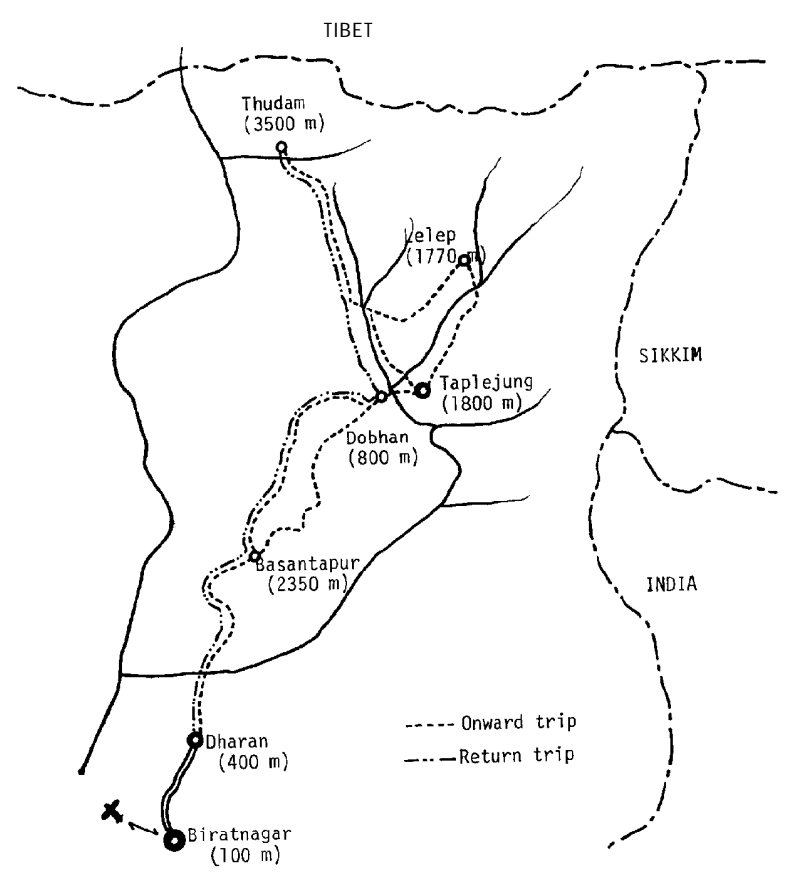

Map 1. Route of Kyushu University Scientific Expedition to the Nepal Himalaya in $\mathbf{1 9 7 2}$.

All the types of new species described in this paper are preserved in the Biological Laboratory, College of General Education, Kyushu University, Fukuoka.

We wish to thank to Professor Y. Hirashima and-Associate Professor K. Morimoto of Kyushu University for their continuous guidance. Our thanks are due to Professor Emeritus T. Shirôzu and Professor T. Saigusa of Kyushu University for their help to the expedition; We also would like to thank Associate Professors A. Nakanishi and H. Shima of Kyushu University for their helpful suggestions.

\section{Subfamily Prioninae}

\section{Dorysthenes (Lophosternus) indicus (Hope) (Fig. 5)}

Prionus indicus Hope, 1831, Gray's Zool. Misc.,: 27 (Nepal).

Lophosternus (Cyrtosternus) hopei Guér., 1844, Icon. Règne Anim., Ins.,: 210.

Lophosternus indicus: Gahan, 1906, Fauna Brit. India, Col., 1: 10, fig. 3 (Nepal, Bhutan, Sikkim). 
Dorysthenes (Lophosternus) indicus : Lameere. 1913, Col. Cat., 52: 68 (Assam bis Nepal) ; Lameere, 1919, Genera Ins., 172: 127; Villiers et Chûjô, 1966, Jour. Coll. Arts \& Sci., Chiba Univ. Nat. Sci., 4(4): 550 (Nepal) ; Hayashi, 1979, Ent. Rev. Japan, 33(1/2): 84, pl. 1, fig. 3 (Nepal).

Specimen EXAmined :1ð, Papun (alt. 2100m), E. Nepal, 10. vi. 1972, H. Shima leg,

Distribution : Nepal, Bhutan, Sikkim.

Dorysthenes (Lophosternus) huegelii (Redtenbacher) (Fig. 6)

Cyrtognathus Hügelii Redtenbacher, 1848, Hügel's Kaschmir IV, 2: 550, pl. 28, fig. 1 (Kashmir). Cyrtognathus falco Thomson, 1877, Rev. Mag. Zool.,: 262 (Darjeeling).

Lophosternus hügelii: Gahan, 1906, Fauna Brit. India, Col., 1: 11 (Kashmir, N. W. Provinces, Panjab, Assam) ; Stebbing, 1914, Ind. For. Ins., :274, pl. 12 (India).

Lophosternus palpalis Gahan, 1906, Fauna Brit. India, Col., 1: 12 (Himalaya).

Dorysthenes (Lophosternus) Hügelii+var. falco \& palpalis: Lameere, 1911, Ann. Soc. ent. Belg. 55: 330; Lameere, 1913, Col. Cat., 52: 69; Lameere, 1919, Genera Ins., 172: 128.

Dorysthenes (Lophosternus) hügelii: Hayashi, 1979, Ent. Rev. Japan, 33(1/2): 85 (Nepal).

SPectmen examined: 1 우, Hile (alt. $2100 \mathrm{~m}$ ), E. Nepal, 13. vi. 1972,H. Makihara leg.

Distribution: N. W. India, Himalayas, Nepal, Sikkim.

Sarmydus subcoriaceus (Hope) (Figs. 1, 7)

Prionus subcoriaceus Hope, 1831, Gray's Zool. Misc.,: 27 (Nepal).

Sarmydus subcoriaceus : Gahan, 1906, Fauna Brit. India, Col., 1: 51 (Nepal) ; Lameere, 1912. Mem. Soc. ent. Belg., 21: 32; Lameere, 1913, Col. Cat., 52: 83; Lameere, 1919, Genera Ins., 172: 128 .

SPectmens examined: 1 ð, Basantapur (alt. $2350 \mathrm{~m}$ ), E. Nepal, 29. vii. 1972, H. Makihara leg. ; 1 ๙, Papun (alt. $2100 \mathrm{~m}$ ), E. Nepal, emerged from a decayed vine, 28. vii. 1972, H. Makihara leg.

DistRIBUTION : Nepal.

Diagnosis: This species is related to S. antennatus Pascoe from Sunda Is., Burma, Assam, Andaman Is., Taiwan, Laos, but differs from it in the following points in male.

S. subcoriaceus (Hope) : Head and 1st antenna1 segment somewhat roughly

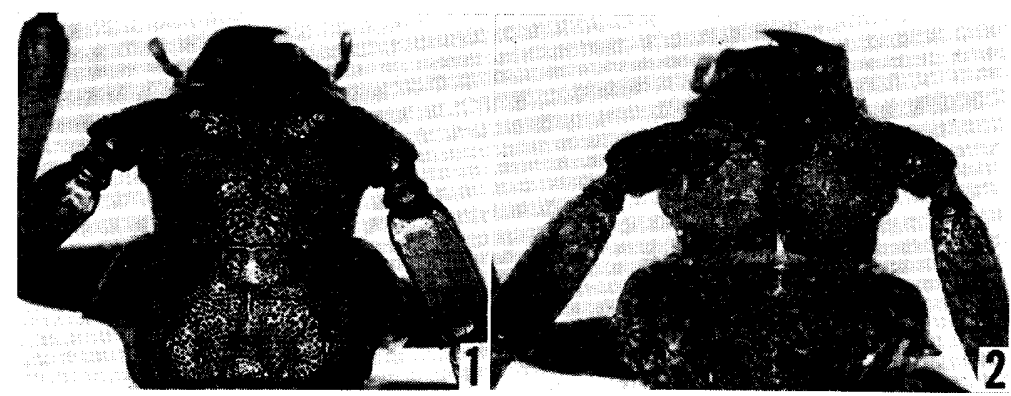

Figs. 1 and 2. Head and pronotum of Sarmydus spp. 1: subcoriaceus from Nepal. 2 : antennatus from -Taiwan. 
punctured ; eyes widely separated ; 1st antenna1 segment somewhat rounded ; 3rd antenna1 segment not punctured and shining on basal $1 / 4$, and finely punctured on apical 3/4; elytra strongly punctured.

S. antennatus Pascoe of Taiwan: Head and 1st antenna1 segment strongly and roughly punctured; eyes narrowly separated ; 1st antenna1 segment angulated; 3rd antenna1 segment sharrowly punctured all over; elytra weakly punctured.

\section{Subfamily LEPTURINAE}

Strangaliella emotoi sp. nov. (Fig. 9)

Female. Body black, elytra fulvous brown with black vittae and markings as the following manner: base, suture and margins (excepting fulvous sides of humeri) narrowly and apices broadly black; a slightly arcuate longitudinal vitta starting from just outside the middle between humerus and scutellum of base widely interrupted in the middle, and broader behind the middle to apex; a rectangular marking narrowly marginating humeral corner ; a narrow ill-defined longitudinal vitta just inner side of the first vitta on second quarter of disc; a broad concave arc from the middle of outer margin posterointernally to the middle of disc. Antennae black with white 8th (excl. extreme base), 9th, 10th segments and extreme base of 11th; 3rd to 6th abdominal segments fulvous brown decorated with black markings at sides of basal halves, the markings of 4 th more developed than the preceding ones; femora reddish light brown, tibiae and tarsi infuscated.

Body thinly covered with golden yellow pubescence, which is dense on apical constriction, medioposterior center and both sides of basal one third of prothorax, breast and on abdomen.

Head dull, broader than long, abbreviated in front, narrower than prothorax at base, with relatively long genae, and very short temples, immediately narrowed posteriorly from just behind eyes to a distinct neck, very closely punctured throughout, the interspaces minutely granulate, with a fine median longitudinal furrow, short frons and relatively long clypeus divided by a narrow triangular impression, occipital plane broad, clypeus shining, sparsely punctured, neck very sparsely punctured, shining. Eyes prominent. Antennae $\mathbf{1 . 0 8}$ times as long as body, slender ; scape weakly dilated apically, arcuate ; relative length of each segment $7.4: 1.7: 12.7: 10.5: 12.7: 9.7: 9.7$ : $8.9: 8.5: 8.0: \mathbf{1 0 . 1}$.

Prothorax broad campanuliform, as long as broad, strongly constricted behind apex, distinctly convex above, hind angles blunt, not prolonged acutely far from humeri; disc with very close fine punctures and granules throughout as on head, dull.

Scutellum narrow tongue-shaped, incised at apex.

Elytra distinctly broader than prothorax at base, strongly narrowed 
posteriorly from humeri to posterior quarter, obliquely and rather broadly truncate at apex, suture slightly dehiscent posteriorly from base to apical quarter, then slightly broadened to apex, outer marginal angles blunt.

Legs relatively long, slender ; femora weakly thickened, posterior pair arriving at 4 th abdominal segment; tibiae slender; hind tarsi with 1 st segment longer than following two segments united.

Length : $\mathbf{1 1 . 0} \mathrm{mm}$, width : $2.9 \mathbf{~ m m}$.

Distribution : East Nepal.

Type material: Holotype 우, Basantapur (alt. 2350 m), E. Nepal, 29. iv. 1972, J. Emoto leg.

Diagnosis: This new species which is known by the female only is related to S. subapicalis (Gressitt) from Taiwan, but differs from it in the following points.

S. emotoi sp. nov. : 8th antenna1 segment (excl. extreme base) white; middle part of prothorax closely punctured, dull; basal part of elytra with a narrow ill-defined longitudinal marking near suture; 3rd to 6 th abdominal segments with black markings at sides of basal halves.

S. subapicalis (Gressitt) : 8th antenna1 segment white on apical $1 / 2$; middle part of prothorax not punctured, shining; basal part of elytra without markings near suture; 3rd to 6th abdominal segments without black markings at sides of basal halves.

Idiostrangalia quadrisignata sp. nov. (Fig. 10)

Male. Body light fulvous brown, covered with thin golden yellow pubescence throughout; tips of mandibles deep reddish brown to black; occiput black ; vertex brown; terminal segments of palpi piceous or blackish brown; eyes black; prothorax broadly marginate at apex and narrowly at base, with two longitudinal wide black vittae on dorsum ; scutellum black ; elytra narrowly marginate at base, with two black fasciae in the middle and a quarter from apex which almost reaching side margins and narrowly interrupted at suture, narrowly darkened at side margins from posterior portion of humeri to the posterior black fascia, suture black from base to portion a little beyond the posterior fascia. Antennae slightly brownish on scape;distictly annulated with black at apices of 3rd, 4th and 5th segments, and narrowly at apex of 6th segment; apical third of 11 th segment dark brown. Apical and lateral portions of prosternum and meso- and metathoracic sterna (excepting yellow central portion of mesosternum) and abdomen black. Apical halves of hind femora, claw segments and claws of front tarsi, middle and hind tarsi and tibiae brownish. Underside densely covered with brown pubescence.

Head broader than prothorax, abbreviated in front, clypeus punctured, frons scattered with very fine and sparse shallow punctures, shining, with a median longitudinal furrow from apex of frons to narrow dull vertex, vertex densely and finely punctured, occiput and genae short, temples almost invis- 
ible, immediately narrowed posteriorly to distinct neck behind the well developed eyes. Antennae 0.92 times as long as body, reaching just before elytral apex, scarcely impressed on apices of distal segments, relative length of each segment $8.9: 1.3: 11.8: 8.4: 12.4: 10.9: 10.4: 8.5: 8.5: 8.0: 10.2$.

Prothorax elongate campanuliform, distinctly constricted behind apex, rather strongly dilated at sides anterior to the middle, then parallel-sided for a short distance and broadened posteriorly to weakly developed hind angles, base bisinuate, disc convex, finely and closely punctulate throughout.

Scutellum triangular.

Elytra broader than prothorax, slender, about 3.3 times as long as the basal width, distinctly narrowed posteriorly to the middle, then very weakly narrowed to obliquely truncate apex, slightly dehiscent at median suture near apex, disc finely and closely punctured throughout.

Thorax and abdomen covered with dense golden yellow pubescence; apical half of 5th abdominal tergite exposed behind elytra; 7th abdominal sternite strongly and deeply hollowed throughout, and the tergite with a pair of deep incisions.

Legs slender, hind femora surpassing 6th abdominal segment and not reaching the apex of elytra, 1st segment of hind tarsus less than twice as long as two followings combined.

Length : $11.8 \mathrm{~mm}$, width : $2.4 \mathrm{~mm}$.

DisTRIBUTion : East Nepal.

Type Material: Holotype $\precsim$, Lelep (alt. 1770 m), E. Nepal, 1. vi. 1972, H. Shima leg.

Diagnosis: This new species which is known by the male only is related to Idiostrangalia bisbilineata (Pic) from Tonkin, but differs from it in the following points : Basal parts of elytra without black markings, and abdomen black. This is related also to I. sozanensis (Mitono) from Taiwan, but differs from it in the following characters: Pronotum with a pair of wide black portions on each side; elytra with two small black fasciae; vertex black.

\section{Subfamily Cerambycinae}

\section{Hoplocerambyx spinicornis (Newman) (Fig. 13)}

Hammaticherus spinicornis Newman, 1842, Entomologist, 1: 245 (Philippines). Cerambyx? morosus Pascoe, 1857, Trans. ent. Soc. London, (2) 4: 92 (Borneo). Hoplocerambyx relictus Pascoe, 1866, Proc.zool.Soc. London, 1866 : 528 (Malaya). Hoplocerambyx spinicornis : Gahan, 1906, Fauna Brit. India, Col., 1: 131, fig. 50 (Nepal, Assam, Tennaserim, S. Afghanistan, Penang, Singapore, Sumatra, Borneo, Philippine Is.) ; Aurivillius, 1912, Col. Cat., 39: 56 (Philippinen, Borneo, Sumatra, Malacca, Bengalen) ; Stebbing, 1914, Ind. For. Ins.,: 320, pl. 22 (India) ; Duffy, 1968, Imm. Stage Orient. Timb. Beetles,: 89, figs. 44-49 (Borneo, Burma. Bhutan, India, Indo-China, Malaya, Nepal, Afghanistan, Pakistan, Philippine Is., Singapore, Sumatra, Thail and, Palau Is., New Guinea); Gressitt \& Rondon, 1970, Pac. Ins. Mon., 24: 70, fig. 14 a (Vietnam, 
Laos); Hayashi, 1975, Bull. Osaka Jonan Women's Coll., 10: 176 (Malaya, Sabah, Sarawak) ; Hayashi, 1979, Ent. Rev. Japan, 33(1/2): 86, pl. 1, fig. 6 (Nepal).

Specimens examined: $1 \hat{\sigma}$, Dharan (alt. 400 m), E. Nepal, 9. vi. 1972, H. Makihara leg. ; $1 \delta$, Kathmandu (alt. 1350 m), C. Nepal, 5. viii. 1972, H. Makihara leg.

Distribution: Laos, Pakistan, Afghanistan, Bhutan, Nepal, India, Burma, Indo-China.

Rhytidodera simulans (White) (Fig. 15)

Hammaticherus ? simulans White, 1853, Cat. Col. Brit. Mus., 1 : 132 (Tenasserim, S. Borneo). Rhytidodera simulans: Pascoe, 1866, Proc.zool.Soc. London, 1866: 531 (Malacca) ; 1869,

Trans. ent. Soc. London, (3)3: 525 (Malacca) ; Gahan, 1906, Fauna Brit. India, Col.,

1: 148 (Malay Peninsula, Borneo, Ceram) ; Aurivillius, 1912, Col. Cat., 39: 62 ; Hayashi, 1972, Res. Rep. Osaka Priv. Jr. Coll. Assoc., 9: 25 (Borneo, Sabah) ; Hayashi, 1976, Bull. Japan ent. Acad.,9(2): 27 (Borneo).

Specimen examined: 1 우, Dharan (alt. 400 m), E. Nepal, 9. vi. 1972, H. Makihara leg.

Distribution : Borneo, W. Malaysia, Thailand, Burma, Nepal.

Stromatium barbatum (Fabricius) (Fig. 14)

Callidium barbatum Fabricius, 1775, Syst. Ent., : 189 (Ostindien).

Callidium funestum Boisd., 1835, Voy. d'Astrolabe, 2: 481 (Madagascar).

Stromatium barbatum: Gahan, 1906, Fauna Brit. India, Col., 1: 114, fig. 45 (India, Ceylon, Burma, Andamans, Bourbon, Madagascar) ; Aurivillius, 1912, Col. Cat., 39: 73 (Ostindien, Ceylon, Burma, Andamans, Madagascar, Mauritius, Bourbon, Seychellen); Stebbing, 1914, Ind. For. Ins.,: 291, fig. 201 (India) ; Villiers et Chûjô, 1966, Jour. Coll. Arts \& Sci., Chiba Univ., Nat. Sci., (4): 550 (Nepal); Hayashi, 1979, Ent. Rev. Japan, 33(1/2): 86, fig. 7 (Nepal).

Specimen examined : 1 ๙, Biratnagar (alt. $100 \mathrm{~m}$ ), E. Nepal, 8. vi. 1972, H. Makihara leg.

Distribution: E. India, Nepal, Ceylon, Burma, Andaman Is., Bourbon \& Seychelles Is., Mauritius, Madagascar, Bangladesh (2 우우, Dacca, 1. v. 1979, K. A. Sahad leg.).

Rosalia (Eurybatus) nakanishii sp. nov. (Figs. 3, 17)

Female. Body depressed. Head, antennae, scutellum and metasternum black; legs and ventral side of body (except for metasternum) dark blackish red; pronotum dark vermilion.

Head shining; basal part of mandibles and genae irregularly and roughly punctured ; frons and vertex irregularly and closely punctured; gula not punctured. Antennae short, 0.95 times as long as body, relative length of each segment $7.8: 2.2: 15.0: 13.3: 12.9: 10.0: 9.4: 7.2: 7.8: 6.1: 8.4$; each segment finely and closely punctured; 3rd to 6 th segments with curved teeth endoapically, a teeth on 3rd well developed; with dense prostrate black hairs on apical $1 / 3$ of 3 rd to 5 th segments; with prostrate blackish brown pubescence on lst, 
2nd, 6th to 11 th and basal portions of 3 rd to 5 th segments; with suberect sparse long brown bristles on ventral sides of 1 st and 2 nd, ventral sides of 3rd and 4th (except for apical 1/4) and apical parts of 5th to 10th segments.

Prothorax $2 / 3$ times as long as broad, with dense suberect dark vermilion pubescence except for dorsolateral tubercles, with sparse long golden yellow hairs; dorsolateral tubercles with dense erect black hairs.

Scutellum semicircular, with dense short suberect black hairs.

Elytra 2.15 times as long as broad, with dense prostrate vermilion pubescence, with sparse suberect long golden yellow hairs, each with two small black pubescent spots on lateral portion, a basal one at basal $1 / 5$ and another at apical $1 / 3$.

Ventral surface of body finely and closely punctured, with dense prostrate short brown pubescence ; prosternum, prosternal process and mesosternum with sparse suberect yellowish brown hairs.

Legs long and slender; fore legs and middle tibiae closely punctured; middle (except for tibiae) and hind legs sparsely punctured ; with dense suberect short brown hairs on fore legs, middle tibiae and hind tibiae; with sparse suberect long brown hairs on fore tibiae, middle femora and hind legs.

Length : $25.0 \mathrm{~mm}$, width : $8.5 \mathrm{~mm}$.

Distribution: Central Nepal.

Type Material: Holotype of, Bogara (alt. $1740 \mathrm{~m}$ )-Dobang (alt. $2350 \mathrm{~m}$ ), C. Nepal, 23. ix. 1971, A. Nakanishi leg.

Diagnosis: This new species which is only known by the female is related to Rosalia (Eurybatus) gravidus Lameere from Sikkim, but differs from it in the following points.

$R$. (E.) nakanishii sp. nov. (Fig. 3) : Antennae short, 0.95 times as long as body; elytron with two small black markings on lateral side, the basal one at basal $1 / 5$ and another one at apical $1 / 3$.

$R$. (E.) gravidus Lameere (Fig. 4) : Antennae rather long, longer than body; elytron with a large black marking in the middle and often with another smaller one under humeri.

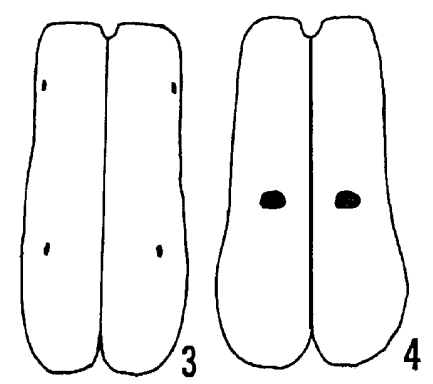

Figs. 3 and 4. Elytral markings of Rosalia (Eurybatus) spp. 3 : nakanishii sp. nov. 4: gravidus from Darjeeling. 


\section{Rosalia (Eurybatus) lateritia (Hope) (Fig. 16)}

Lamia Zateritia Hope, 1831, Gray's 2001. Misc., : 27 (Nepal).

Eurybatus Zateritius: Lameere, 1887, Ann. Soc. ent. Belg., 31: 165, pl. 3, fig. 3 (Himalaya).

Rosalia (Eurybatus) lateritia: Gahan, 1906, Fauna Brit. India, Col., 1: 177 (Himalayas, Travancore, Burma, Indo-China); Aurivillius, 1912, Col. Cat., 39: 330; Hayashi, 1979, Ent. Rev. Japan, 33(1/2): 86, pl. 1, fig. 9.

Eurybatus (Eurybatorosalia) Zateritius: Plavilstshikov, 1933, Best.-Tab. eur. Col., 112 : 144 (+abb. verticerubra + scutellaris + humeralis + humerobipunctatus + humerostriatus + mediopunctatus; $N$. India, Sikkim, Assam, Burma).

Rosalia (Eurybatorosalia) Zateritia : Plavilstshikov, 1932, Ent. Nachrichtenblat, 6(4): 88 (+abb. verticerbra + scutellaris + humeralis + humerobipunctatus + humerostriatus + mediopunctatus).

Specimen examined : 1 우, Dobang (alt. 2350 m), C. Nepal, 10. x. 1971, A. Nakanishi leg.

Distriburion: Himalayas, N. India, Nepal, Sikkim, Assam, Burma, Indo-

China.

Glaphyra shimai sp. nov. (Figs. 11, 12)

Body black, antennae light brown basally and successively darkened distally, legs light reddish brown or light orange brown, femora (especially of middle and hind pairs) yellowish at base and annulated in the middle with black, tibiae and tarsi darkened; elytra light brown, with dark chestnut brown on apical third. Body covered with fine pale fulvous whitish grey pubescence, which is dense at sides of apical and basal constrictions, scutellum and on sides of abdominal segments, additionally with sparse erect long silver grey hairs on body and the underside of antennae.

Head as broad as prothorax, short, distinctly abbreviated in front; frons almost vertical, short, transverse, coarsely and sparsely punctured, with a short median longitudinal furrow, broadly impressed in the middle of apical half; vertex narrow; occiput longitudinally and obliquely multistriolate ; genae very short, about $1 / 10$ as long as the diameter of eye; antenna1 insertions weakly raised and somewhat separated. Eyes finely facetted, distinctly emarginate, lower lobes large, very closely set to mandibles. Antennae 2.32 times (male) or 0.77 times (female) as long as body, ultimate segment minutely appendiculate at apex, scape short and thickened, finely and sparsely punctured, 2nd segment and the succeedings filiform, apices slightly thickened from 3rd to 10th segments, relative length of each segment $3.8: 1.1: 5.7: 6.1$ : 10.4: 10.4: 11.9: 12.4: 12.4: 11.3: 14.6 (male) or $8.6: 4.0: 10.6: 11.2: 14.2$ : $11.2: 9.9: 7.6: 7.6: 6.6: 8.6$ (female).

Prothorax longer than broad (10.5:7.5), constricted behind apex and before base, with a small obtuse tubercle on each side in the middle; disc with coarse subreticulate punctures.

Scutellum quadrate, densely covered with white pubescence.

Mesosternum punctured, leaving a median triangular shining line. 
Elytra as long as prothorax and longer than the basal width, produced anteriorly at humeri, a little expanded laterally behind base, and then gradually narrowed posteriorly to round apices, median suture strongly dehiscent
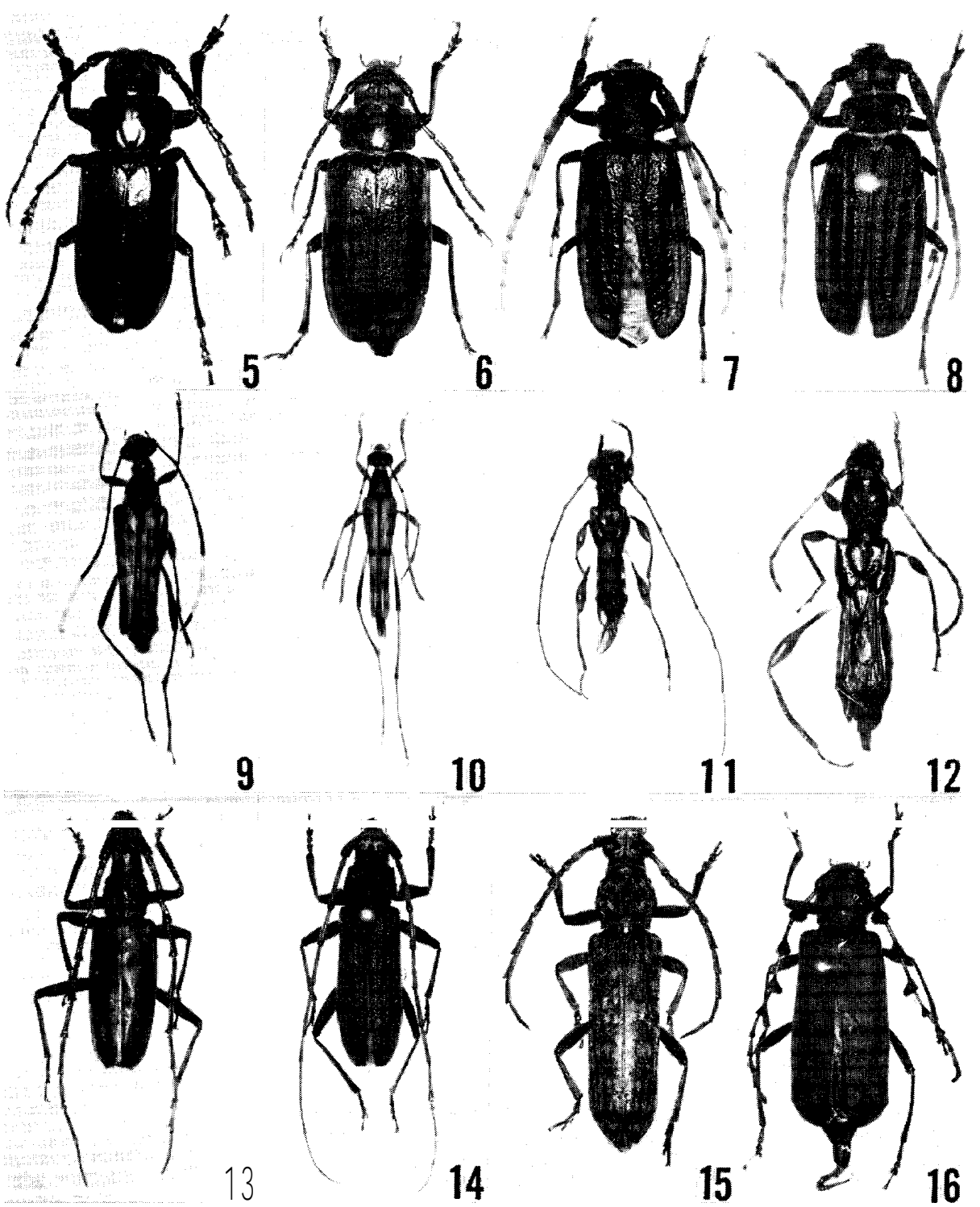

Figs. 5-16. 5 : Dorysthenes (Lophosternus) indicus (Hope). 6 : Dorysthenes (Lophosternus) huegelii (Redtenbacher). 7: Sarmydus subcoriaceus (Hope) from Nepal. 8: Sarmydus antennatus Pascoe from Taiwan. 9: Strangaliella emotoi sp. nov. 10: Idiostrangalia quadrisignata sp. nov. 11: Glaphyra shimai sp. nov., male. 12 : Ditto, female. 13 : Hoplocerambyx spinicornis (Newman). 14 : Stromatium barbatum (Fabricius). 15 : Rhytidodera simulans (White), 16: Rosalia (Eurybatus) lateritia (Hope). 
at apical third; disc obliquely impressed from insides of humeri to apical third of median suture, sparsely punctured on light brown areas and finely so on apical castaneous areas.
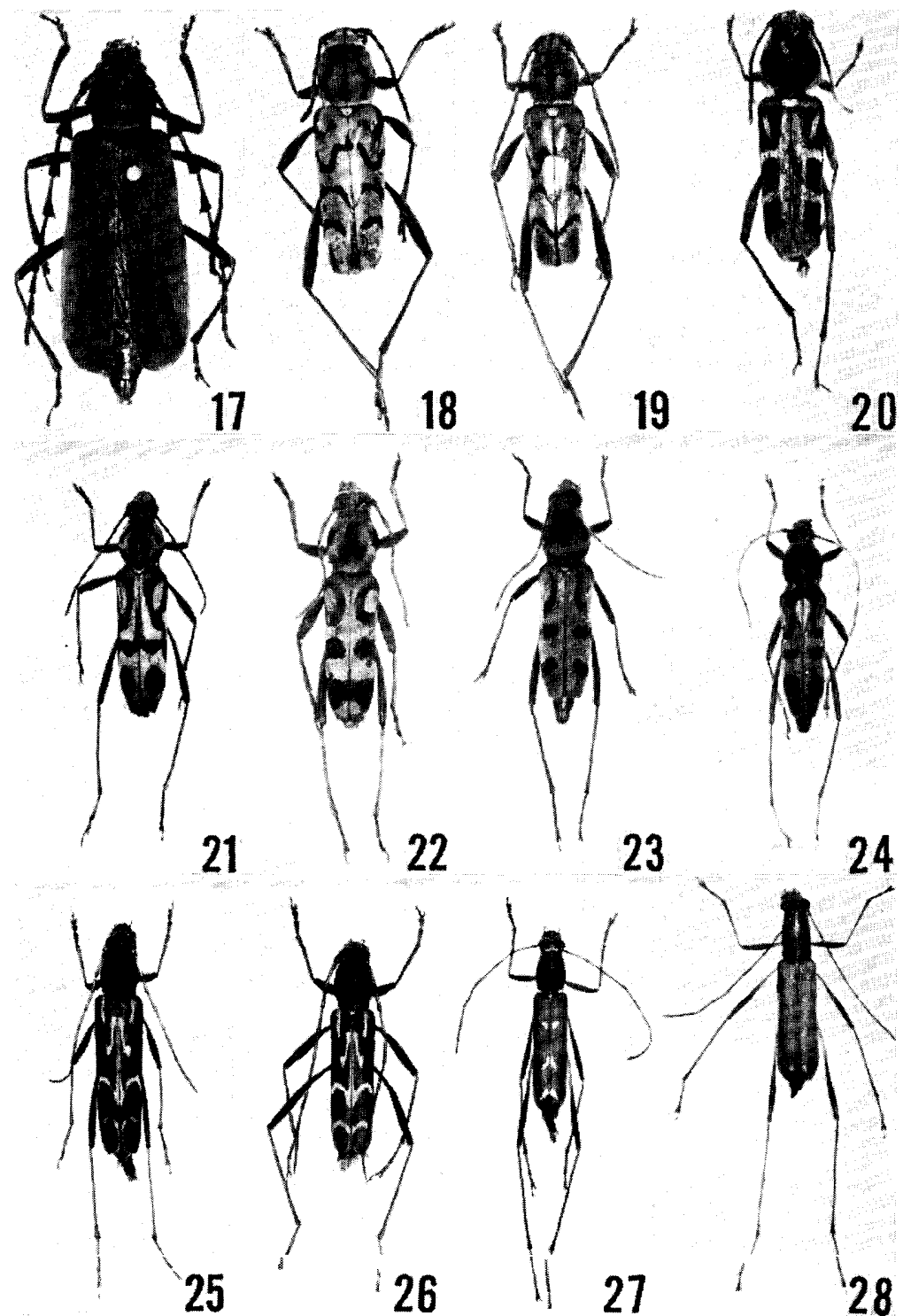

24

Figs. 17-28. Rosalia (Eurybatus) nakanishii sp. nov. 18:Xylotrechus incurvatus incurvatus (Chevrolat) from Taiwan. 19: Xylotrechus incurvatus contortus Gahan from Nepal. 20:Xylotrechus quadripes Chevrolat. 21: Chlorophorus annularis (Fabricius). 22 :Chlorophorus shoreae Gardner. 23 :Chlorophorus assimilis (Hope). 24 : Ckloropkorus arciferus Chevrolat. 25 : Rkaphuma fulgurata Gahan,female. 26: Ditto, male. 27: Rhaphuma nishidai sp. nov. 28: Rkapkuma testaceiceps Pic from Taiwan. 
Ventral side finely punctured.

Legs relatively long, femora pedunculate and strongly clavate, tibiae arcuate, tarsi slender, 1st segment of hind tarsi slightly shorter than the two followings combined.

Length : IO. $0 \mathrm{~mm}$ (male), 9.5-10.0 $\mathrm{mm}$ (female).

Distribution : East Nepal.

Type material: Holotype ठ̋, Shawa (alt. 2300 m), E. Nepal, 9. vi. 1972, H. Shima leg. Paratypes 3 우, same data as holotype ;우, same locality as holotype, 8. vi. 1972, Y. Nishida leg.

\section{Xylotrechus quadripes Chevrolat* (Fig. 20)}

Xylotrechus quadripes Chevrolat, 1863, Mém.Soc. R. Sci. Liege, 18: 312, 315 (Ostindien); Dunning, 1868, Trans ent. Soc. London, 1868: 126 (Burma) ; Gahan, 1900, Ann. Mag. nat. Hist., (7)5: 348 (Hainan) ; Gahan, 1906, Fauna Brit. India, Col., 1: 245, fig. 90 (Madras, Assam, Burma, Siam, Tonkin; Coffee borer) ; Aurivillius, 1912, Col. Cat., 39: 366; Stebbing, 1914, Ind. For. Ins., : 351, fig. 238 (India) ; Beeson et Bhatia, 1939, Ind. For. Rec. (n. s.), Ent., 5: 191; Mitono, 1941, Bull. Agr. For. Taihoku Imp. Univ., 2 : 103, pl. 7, fig. 1 ; Gressitt, 1951, Longicornia, 2: 237, 250 (Hainan, Formosa ?) ; Breuning et Heyrovsky, 1961, Bonn. Zool. Beitr., 12(1/2): 142 (Sikkim); Duffy, 1968, Imm. Stage Orient. Timb. Beetles, : 209; Gressitt et Ronđon, 1970, Pac. Ins. Mon., 24: 200, fig. 33c (Established quadripes group incl. vitalisi $\mathrm{Pic}$ ); Pu, 1980, Econ. Ins. Fauna China, 19: 53, fig. 68 (China, Taiwan).

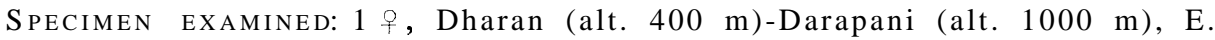
Nepal, 11. vi. 1972, H. Makihara leg.

D istribution: India, Nepal, Burma, Thailand, Tonkin, Hainan I., China, Taiwan.

\section{Xylotrechus incurvatus contortus Gahan* (Fig. 19)}

Xylotrechus contortus Gahan, 1906, Fauna Brit. India, Col., 1: 249 (Sikkim, British Bhutan, Manipur) ; Aurivillius, 1912, Col. Cat., 39: 365; Beeson et Bhatia, 1939, Ind. For. Rec. (n. s.), Ent., 5: 190; Pu, 1980, Econ. Ins. Fauna China, 19: 52, pl. 5, fig. 66 (China). Xylotrechus biarcuatus Pic, 1917, Mel. Exot.- Ent., 24: 6 (S. China; Yunnan).

Xylotrechus incurvatus contortus: Gressitt, 1951, Longicornia, 2 : 234, 245 (China : Szechuan, Fukien, Yunnan).

Specimens examined : 1 ๙, Dobang (alt. 2350 m), C. Nepal, 27. x. 1971, A. Nakanishi leg. ; 1 오, Bogara (alt. 1740 m), C. Nepal, 30. x. 1971, A. Nakanishi leg.

Distribution: N. India, Nepal, Assam, China (Yunnan, Szechuan, Fukien, Kwangsi).

Diagnosis: This subspecies is similar to $\mathrm{X}$. incurvatus incurvatus (Chevrolat) from India, Assam, Burma, China (Hong Kong), Taiwan, but differs from it in the following points.

X.incurvatus contortus Gahan (Fig. 19) : Smaller (10-11 mm), slender, with prostrate pale yellow pubescence ; scutellum semicircular; pronotum with dark 
brown pubescent markings ; elytra with dark brown pubescent bands; apical spines of elytra developed.

X. incurvatus incurvatus (Chevrolat) (Fig. 18) : Larger (13-14 $\mathrm{mm}$ ), robust, with prostrate orange pubescence ; scutellum triangular ; pronotum with black pubescent markings ; elytra with blackish brown pubescent bands ; apical spines of elytra not so developed.

\section{Chlorophorus annularis (Fabricius) (Fig. 21)}

Callidium annulare Fabricius, 1787, Mant. Ins., 1: 156 (Siam).

Clytus annularis: Fabricius, 1801, Syst. Eleuth., 2: 352; Castelnau et Gory, 1841, Mon. Genre Clytus,: 102, pl. 19, fig. 121; White, 1855, Cat. Col. Brit. Mus., 8: 283 (E. Indies).

Callidium bidens Weber, 1801, Obs. Ent.,: 90.

Chlorophorus annularis: Chevrolat, 1863, Mém.Soc. Sci. Liege, 18: 290; Gahan, 1900, Ann. Mag. Nat. Hist., (7) 5: 348; Aurivillius, 1912, Col. Cat., 39: 402 (Ostindien, Assam, Birma, Siam, China, Japan, Malacca, Java, Timor, Molukken, Aru, New Guinea); Kano, 1931, Bull. biol. Soc. Japan, 2: 183 (Japan, Taiwan) ; Matsushita, 1933, Jour. Fac. Agr. Hokkaido Imp. Univ., 34: 280 (Japan, Taiwan) ; Cheo, 1935, Peking Nat. Hist Bull., 10: 9 (China) ; Shiraki et al, 1937, Surv. Inj. Ins. Taiwan Agr. Crops, 4: 107, fig. 89 (Taiwan) ; Gressitt, 1939, Lingnan Sci. Jour., 16: 454 (China) ; Beeson et Bhatia, 1939, Ind. For. Rec. (n. s.) Ent., 5: 44 (India) ; Gressitt, 1940. Phil. Jour. Sci., 73: 74 ; Gressitt, 1942, Lingnan Nat. Hist. Sci. Mus. Spec. Publ., 1: 32, fig. 22 (China) ; Gressitt, 1942, Lingnan Sci. Jour., 20: 214 (China) ; Chiang, 1942, Lingnan Sci. Jour., 20: 256 (China); Gressitt, 1951, Longicornia, 2: 275 (Taiwan, China); Gressitt, 1951, Phil. Jour. Sci. 79(2): 214 (The Ryukyus) ; Hayashi, 1962, Ent. Rev. Japan, 14(1): 11 (The Ryukyus) ; Kojima et al, 1965, Res. Rep. Kochi Univ., 14, Nat. Sci., Z(9): 85 (The Ryukyus) ; Samuelson \& Gressitt, 1965, Pac. Ins., 7(1): 77 (The Ryukyus) ;Villiers et Ch ûjô, 1966. Jour. Coll. Arts \& Sci., Chiba Univ., Nat. Sci., 4(4): 551 (Nepal) ; Kojima et Hayashi, 1969, Ins. Life Japan, 1: 82, pl. 25, fig. 1 (Japan) ; Gressitt \& Rondon, 1970, Pac. Ins. Mon., 24: 221, fig. 35 g (Laos) ; Nakane, 1977, Ins. Nat., 12(3):8 (Japan) ; Makihara, 1979, Esakia, 14: 165, figs. 39, 43A (Okinawa of the Ryukyus) ; Hayashi, 1979, Ent. Rev. Japan, 33(1/2): 88, pl. 2, fig. 1 (Nepal) ; Pu, 1980, Econ. Ins. Fauna China, 19: 59 (China).

Clytanthus annularis: Pascoe, 1869, Trans ent. Soc. London, (3)3:601 (Sarawak, Macassar. Ternate, Gilolo, Morty, Batchian, Bouru, Ceram, Aru, Flores, Timor).

Caloclytus annularis: Gahan, 1906, Fauna Brit. India, Col., 1: 261 (N. India, Assam, Burma, Siam, China, Japan, Malay Peninsula, New Guinea) ; Stebbing, 1914, Ind. For. Ins.,: 354, fig. 240 (India).

Specimens examined : 1 , Dobhan (alt. 800 m), E. Nepal, 24. vi. 1972, H. Makihara leg. ; $2 \Varangle 31$ 으, Taplejung (alt. 1800 m), E. Nepal, 25. vi. 1972, H. Makihara leg. ; 1 \& , Taplejung-Handlung (alt. 800 m), E. Nepal, 26. vi. 1972. H. Makihara leg.; $1 \precsim$, Linba (alt. $1500 \mathrm{~m}$ )-Papun (alt. $2100 \mathrm{~m}$ ), E. Nepal, 28. vi. 1972, H. Makihara leg. ; $1 \delta^{\star}$, Dharan (alt. $400 \mathrm{~m}$ ), E. Nepal, 2. viii. 1972, H. Makihara leg.

DisTripution: Japan, Korea, Taiwan, China, Burma, Thailand, Malaya, Philippines, India, Malaysia, Cambodia, Ceylon, New Guinea, Vietnam, Hainan I., Laos, Sunda Is., Nepal. 
Chlorophorus arciferus (Chevrolat) (Fig. 24)

Amauraesthes arciferus Chevrolat, 1893, Mém. Soc. Sci. Liège, 18: 330 (Darjeeling).

Caloclytus arciferus: Gahan, 1906, Fauna Brit. India, Col., 1: 263 (Darjeeling, Bhutan).

Caloclytus socius Gahan, 1906, Fauna Brit. India, Col. 1: 264 (Darjeeling).,

Chlorophorus arciferus: Aurivillius, 1912, Col. Cat., 39: 403; Gressitt \& Rondon, 1970, Pac.

Ins. Mon., 24: 230, fig. 36h-i (Laos) ; Hayashi, 1979. Ent. Rev. Japan, 33(1/2) : 91, pl. 2,

fig. 2 (Nepal).

Chlorophorus varius var. pieli Pic, 1924, Mél.Exot.-Ent., 41: 15 (Shanghai).

Specimen examined: 1 \% , Jilikinpthi (alt. 1850 m)-Pontak (alt. 1800 m), E.

Nepal, 13. v. 1972, J. Emoto leg.

Distribution: $\boldsymbol{N}$. India, Bhutan, Nepal, Laos, China.

Chlorophorus shoreae Gardner* (Fig. 22)

Chlorophorus shoreae Gardner, 1941, Ind. Jour. Ent., 3(1): 55 (India).

SPECIMEN EXAMINED : 1 우, Handlung (alt, $800 \mathrm{~m}$ ) - Linba (alt. 1500 m), E. Nepal, 27. vi. 1972, H. Makihara leg.

Distribution: Nepal, India.

Chlorophorus assimilis (Hope) (Fig. 23)

Clytus assimilis Hope, 1831, Gray's 2001. Misc.,: 28 (Nepal).

Caloclytus assimilis: Gahan, 1906, Fauna Brit. India, Col., 1: 269 (Nepal).

Specimen examined : 1 , , Papun (alt. 2100 m), E. Nepal, 15. vii. 1972, H. Makihara leg.

Distribution : Nepal.

Rhaphuma fulgurata Gahan* (Figs. 25, 26)

Rhaphuma fulgurata Gahan, 1906, Fauna Brit. India, Col., 1 : 274 (Sikkim).

Specimens examined: 1 ð, Basantapur (alt. 2350 m), E. Nepal, 15. vi. 1972, H.

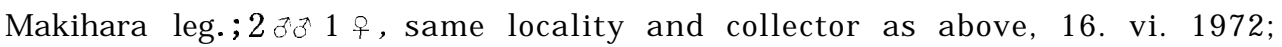
1 ơ, Basantapur-Chowki (alt. 2000m), E. Nepal, 21. vi. 1972, H. Makihara leg.

Distribution : Nepal, Sikkim.

\section{Rhaphuma nishidai sp. nov. (Fig. 27)}

Female. Body slender. Head and thorax black; pronotum, antennae, fore legs, middle legs except for basal $1 / 3$ of femora, basal half of hind tibiae and abdominal sternites (except for lateral side) light reddish brown; elytra pale reddish brown; basal $1 / 3$ of middle femora and basal halves of hind femora yellowish brown; hind legs except for basal halves of femora and tibiae brown; lateral side of abdominal sternites dark brown. Pronotum decorated with a small white pubescent marking on each side at base. Elytra except for following three pubescent bands, i.e, a small band at basal 3/10 near 
median suture, two oblique ones in the middle and at apical $1 / 5$ near median suture, covered not so densely with suberect golden yellow hairs.

Head somewhat roughly punctured, with coarse suberect yellowish white pubescence and with sparse erect long white hairs; antennae short, 0.98 times as long as body, relative length of each segment $6.6: 3.3: 12.8: 11.7$ : $16.3: 13.0: 11.2: 7.7: 6.4: 5.1: 5.9$, with sparse erect short brown hairs, with sparse suberect long brown setae on ventral sides of 2 nd to 6 th segments, and with dense prostrate short brown pubescence on 6th to 11th segments.

Pronotum 1.36 times as long as broad, finely punctured except for apical part, with sparse erect long whitish yellow hairs and dense prostrate short yellowish brown hairs.

Scutellum pentagonal, with dense prostrate white pubescence.

Elytra parallel-sided and slender, 3.48 times as long as broad, rounded at apices, finely punctured.

Thorax closely punctured, with dense prostrate whitish yellow pubescence.

Abdominal sternites shining, closely punctured, with pubescence on lateral sides similar to that on breast.

Legs slender, with suberect long brown hairs.

Length : $10.0 \mathrm{~mm}$, width : $2.0 \mathrm{~mm}$.

Distribution: East nepal.

Type material: Holotype, 오, Samda (alt. 1900 m)-Chisopani (alt. 2100 m), E. Nepal, 15. v. 1972, Y. Nishida leg.

DiAgnosis: This new species which is known by the female is related to $R$. testaceiceps Pic from Taiwan, but differs from it in the following points.

Rhaphuma nishidai sp. nov. : Head black; antennae shorter than body; relative length of each segment $6.6: 3.3: 12.8: 11.7: 16.3: 13.0: 11.2: 7.7: 6.4$ : 5.1 : 5.9; pronotum closely and finely punctured ; pronotum with two white pubescent markings at base; elytra with three white pubescent bands.

R. testaceiceps Pic (Fig. 28) : Head dark reddish brown; antennae longer than body; relative length of each antenna1 segment $6.5: 2.9: 13.2: 10.3$ : $14.7: 12.6: 10.9: 8.8: 7.6: 5.9: 6.7$; pronotum roughly punctured except median portion ; pronotum without marking ; elytra with a white pubescent marking.

This new species is also somewhat similar to Demonax testaceus (Hope) from Nepal, but clearly different from it in having the head black and the antennae not armed with spines.

Demonax albicinctus (Hope) (Figs. 30, 31)

Clytus albicinctus Hope, 1831, Gray's Zool. Misc.,: 27 (Nepal) ; White, 1855, Cat. Col. Brit.

Mus., 8: 280.

Clytus jiliformis Laporte et Gory, 1841, Mon. Clytus,: 95, pl. 18, fig. 112.

Anthoboscus albicinctus: Chevrolat, 1863, Mém.Soc. Sci. Liège, 18: 307.

Demonax albicinctus: Gahan, 1906, Fauna Brit. India, Col., 1: 296 (Nepal). : Aurivillius, 1912, 
Col. Cat., 39: 409; Hayashi, 1979, Ent. Rev. Japan, 33(1/2): 91 (Nepal).

S Pécimens examined: 1 ठ 1 우, Jilikipthi (alt. $1850 \mathrm{~m}$ )-Pontak (alt. $1800 \mathrm{~m}$ ), E. Nepal, 13. v. 1972, Y. Nishida leg.

Distribution : Nepal.

\section{Demonax bicinctus (Hope) (Fig. 29)}

Clytus bicinctus Hope, 1831, Gray's Zool. Misc.,: 28 (Nepal) ; Newman, 1842, Entomologist, 1: 246; White, 1855, Cat. Col. Brit. Mus., 8: 285; Chevrolat, 1863, Mém. Soc. Sci. Liège, 18: 345 (N. India).

Demonax bicinctus: Gahan, 1906, Fauna Brit. India, Col. 1: 294 (Nepal) ; Aurivillius, 1912, Col. Cat., 39: 409.

S Pecimen examined: 1 , Basantapur (alt. $2350 \mathrm{~m}$ ), E. Nepal, 19. vi. 1972, H. Makihara leg.
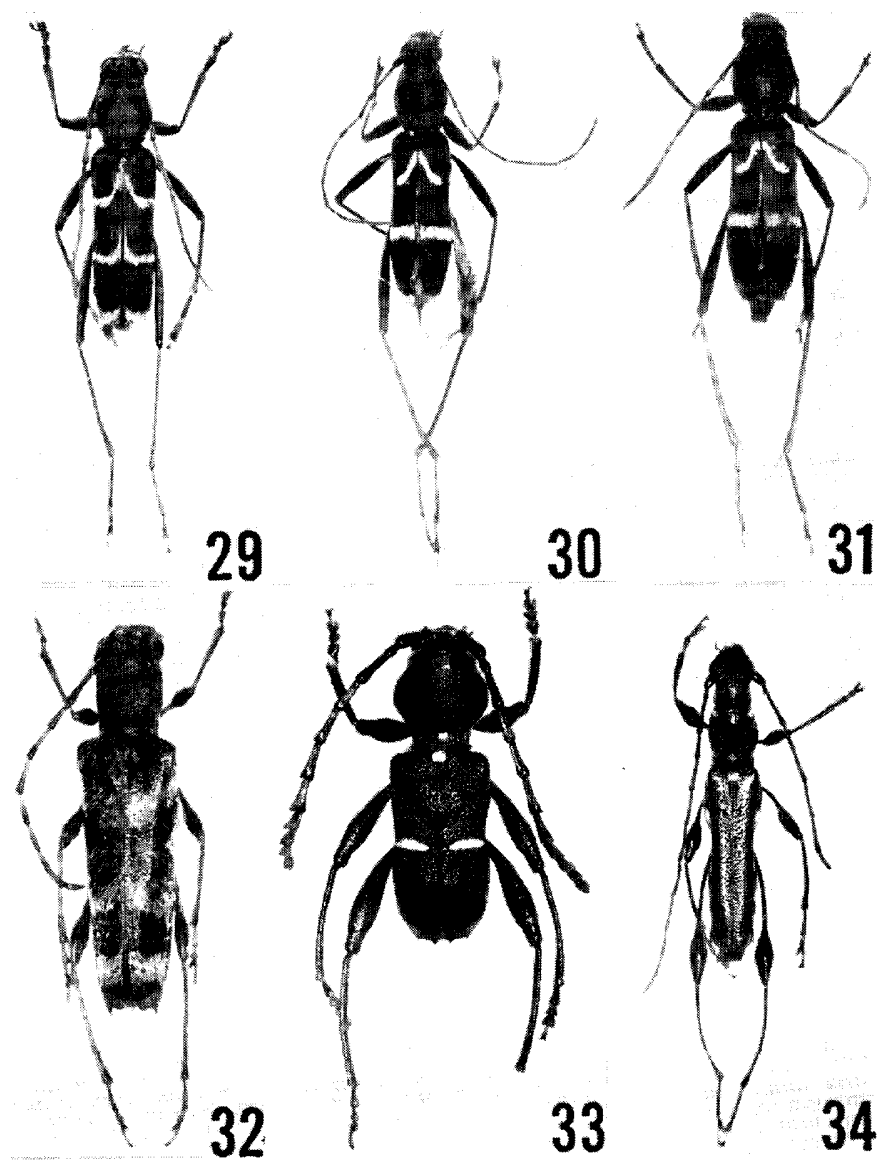

Figs. 29-34. 29 :Demonax bicinctus (Hope). 30: Demonax albicinctus (Hope), male. 31: Ditto, female. 32 : Aglaophis fasciata Thomson. 33 :Epipedocera zona Chevrolat. 34 : Artimpaza obscura Gardner. 
Distribution : Nepal.

Aglaophis fasciata Thomson* (Fig. 32)

Aglaophis fasciata Thomson, 1857, Archiv. Ent., 1: 316 (Sikkim) ; Gahan, 1906, Fauna Brit. India, Col., 1: 304 (Sikkim) ; Aurivillius, 1912, Col. Cat., 39: 416.

Specimen examined: 1 ㅇ, Bogara (alt. 1740 m), C. Nepal, 20. ix. 1971, A. Nakanishi leg.

D istribution : Nepal, Sikkim.

Epipedocera zona Chevrolat (Fig. 33)

Epipedocera zona Chevrolat, 1863, Mém. Soc. Sci. Liege, 18: 340 (Nepal); Gahan, 1906, Fauna Brit. India, Col., 1: 306, fig. 99 (Nepal, Sikkim) ; Aurivillius, 1912, Col. Cat., 39: 423; $\mathrm{Pu}, 1980$, Econ. Ins. Fauna China, 19: 64, p1. 6. fig. 88 (China).

Specimens examined : 1 б 1 우, Dharan (alt. 400 m), E. Nepal, 10. vi. 1972, H. Makihara leg. ; 2 đ̋, Dobhan (alt. 800 m), E. Nepal, 20. v. 1972, Y. Nishida leg, Distribution: Nepal, Sikkim, China.

\section{Artimpaza obscura Gardner* (Fig. 34)}

Artimpaza obscura Gardner, 1926, Ind. For. Rec., 12(7):15 (Assam) ; Duffy, 1968, Imm. Stage, Orient. Timb. Beetles, : 151, fig. 87 (India) ; Gressitt et Rondon, 1970, Pac. Ins. Mon., $24: 289$ (key only).

Specimen examined: 1 \& , Chiliwa (alt. 1350 m)-Sidku (alt. 2100 m), E. Nepal,

7. vi. 1972, Y. Nishida leg.

Distribution : Nepal, India.

\section{References}

Aurivillius, Chr. 1912. Cerambycidae : Cerambycinae. Col. Cat., 39: I-574.

Duffy, E. A. J. 1968. A monograph of the immature stages of Oriental timber beetles (Cerambycidae). British Museum (Natural History), 667 : 1-434, 198 figs. 18 pls.

Gahan, C. J. 1906. Coleoptera 1 (Cerambycidae). Fauna Brit. India, Col., 1: 1-321, 107 figs.

Gressitt, J. L. 1951. Longicorn beetles of China. Longicornia, 2: 1-667, 22 pls.

— \& J. A. Rondon. 1970. Cerambycidae of Laos (Disteniinae, Prioninae, Philinae, Aseminae, Lepturinae, Cerambycinae). Pac. Ins. Mon., 24: I-314, 48 figs.

Hayashi, M. 1976. Studies on Asian Cerambycidae (Coleoptera) 1. Bull. O saka Jonan Women's Junior Coll., 11: 1-24.

- 1976. On some longicorn beetles from Malaysia with descriptions of six new species. Bull. Japan ent. Acad., 9(2): 24-41, 37 figs.

— 1979. Some longicorn beetles of Nepal (Col., Cerambycidae) as the Results of Lepidopterological Research Expedition to Nepal Himalaya in 1963, Part 1. Ent. Rev. Japan, 33 $(1 / 2): 81-96,2$ pls.

Hope, F. W. 1831. Synopsis of new species of Nepal Insects in the collection of Major General Hardwicke. Gray's Zool. Misc.: 21-28.

Kojima, K. \& M. Hayashi. 1969. Insects' life in Japan 1. Cerambycidae : 1-295, 56 pls. Hoikusha, Osaka. (In Japanese)

Lameere, A. 1887. Genre Rosalia. Ann. Soc. ent. Belgique, 31: 159-173, 1 pl. 
1913. Cerambycidae: Prioninae. Col. Cat., 52: 1-108.

1919. Cerambycidae: Prioninae. Gen. Ins.. 172: 1-189, 8 pls.

Makihara, H. 1979. Tribe Clytini of Okinawa Prefecture (Col.: Cerambycidae). Esakia, (14) : 149-173. 56 figs.

Matsushita, M. 1933. Beitrag zur Kenntnis der Cerambyciden des japanischen Reichs. Jour. Fac. Agr. Hokkaido Imp. Univ., 34(2): 157-445, 5 pls.

Mitono, T. 1941. Monography of Clytini in the Japanese Empire (Cerambycidae, Coleoptera) I. Bull. Agr. For. Taihoku Imp. Univ., 2: 74-119, 8 pls.

- 1942. Monography of Clytini in the Japanese Empire (Cerambycidae, Coleoptera) II. Bull. Agr. For. Taihoku Imp. Univ., 3: 79-120, 3 pls.

Pascoe, F. P. 1864-69. Longicornia Malayana. Trans. ent. Soc. London, 3(3): 1-712, 34 pls.

Pic, M. 1923. Nouveautés diverses. Mél. Exot.-Ent., 38: l-32.

Pu, F. 1980. Coleoptera: Cerambycidae II. Econ. Ins. Fauna China, 19: 1-146, 12 pls. (In Chinese)

Stebbing, E. P. 3914. Family Cerambycidae. Indian Forest Insects: 268-385, figs. 187-256.

Tamanuki, K. 1942. Family Cerambycidae. Fauna Japonica 10, 8(15) : l-259, 226 figs. (In Japanese )

Villiers, A. \& M. Chûjô 1966. Coleoptera of East Nepal. Jour. Coll. Arts \& Sci., Chiba Univ. Nat. Sci., 4(4): 533-557.

White, A. 1953. Catalogue of Longicorn Coleoptera. Cat. Col.Brit.Mus., 8: 1-409, 10 pls. 